\title{
Infinitely differentiable functions represented into Newton interpolating series
}

\section{G. GROZA, M. JIANU and N. POP}

\section{ABSTRACT.}

We study infinitely differentiable functions which are representable into a Newton interpolating series at a suitable interpolation sequence with terms in $[0,1]$. Applications of this series to approximate the solution of boundary value problems for linear systems of differential equations are presented.

\section{REFERENCES}

[1] Davis, P. J., Interpolation and approximation, Dover Publication Inc. New York, 1975

[2] El-Gamel, M., Sinc-collocation method for solving linear and nonlinear system of second-order boundary value problems, Applied Mathematics, 3 (2012), 1627-1633

[3] Groza, G. and Pop, N., Approximate solution of multipoint boundary value problems for linear differential equations by polynomial functions, J. Difference Equ. Appl., 14 (2008), No. 12, 1289-1309

[4] Groza, G. and Pop, N., A numerical method for solving of the boundary value problems for ordinary differential equations, Result. Math., 53 (2009), No. 3-4, 295-302

[5] Groza, G., Khan, S. M. Ali and Pop, N., Approximate solutions of boundary value problems for ODEs using Newton interpolating series, Carpathian J. Math., 25 (2009), No. 1, 73-81

[6] Martin, Y., Sur les séries d'interpolation, Ann. Sci. École Norm. Sup., 66 (1949), sér. 3, 311-366

[7] Nurmuhammad, A., Muhammad, M. and Mori, M., SincGalerkin method based on the DE transformation for the boundary value problem of fourth-order ODE, J. Comput. Appl. Math., 206 (2007), 17-26

[8] Shidlowski, A., Transcendental Numbers, de Gruyter, 1989

Department of MATHEMATics AND COMPUter SCIENCE

TECHNICAL UNIVERSITY OF CIVIL ENGINEERING BUCHAREST

124 LaCUl TEI, 020396, Bucharest, Romania

E-mail address: grozag@ut cb.ro

E-mail address: marilena_jianueyahoo.com

InStitute of SOlid Mechanics of the ROMANIAN ACADEMY, BUCHAREST

AND DePartMENT OF MATHEMATICS AND COMPUTER SCIENCE

FACUlty of SCIENCES North University Center at Baia Mare

TECHNICAL UNIVERSITY OF CLUJ-NAPOCA

ViCTORIEI 76, 430122 BAIA MARE, ROMANIA

E-mail address: nicpop@gmail.com

Received: 28.10.2013; In revised form: 27.05.2014; Accepted: 20.10.2014

2010 Mathematics Subject Classification. 41A58, 34B10, 34A45, 65L10.

Key words and phrases. Newton interpolating series, boundary value problems.

Corresponding author: G. Groza; grozag@utcb.ro 